\title{
Analysis of the Use of Bags and Bottle Plastic Containers and Drug Compliance Based on Drug Swallowing Supervisor (DSS) in Reducing the Risk of Pulmonary Tuberculosis Transmission
}

\author{
Sorimuda Sarumpaet ${ }^{1}$, Evawany Aritonang $^{2}$, Lina $\operatorname{Tarigan}^{3}$, Syarifah $^{4}$, Anwar Mallongi $^{5}$ \\ ${ }^{1}$ Lecturer of Department of Epidemiology, ${ }^{2}$ Lecturer of Department of Community Nutrition, ${ }^{3}$ Lecturer of \\ Department of Occupational Health and Safety, ${ }^{4}$ Lecturer of Department of Health Education and Behavioral \\ Sciences, Faculty of Public Health, Universitas Sumatera Utara, 20155, Medan, Indonesia, ${ }^{5}$ Professor of \\ Department of Environmental Health, Faculty of Public Health, HasanuddinUniversity, Makassar Indonesia
}

\begin{abstract}
Tuberculosis (TB) is still prevalent in Indonesia. In 2016, TB's incidence rate is estimated 129 per 100,000 population. In order to reduce the incidence, reducing the risk of transmission through the patient sputum drug compliance is essential.

This is quasi-experimental study design. There are 3 groups, which are the intervention group that receives bag waterproof plastic container, bottle waterproof plastic container that both contains a 4-chloroalphaphenyl-o-cresol (klorofenol) desinfectant with concentration of 5\% as a killer of TB bacilli accompanied by promotional messages and control group (without intervention). The population is all patients with pulmonary TB Acid Fast Bacilli positive ( $\mathrm{AFB}+$ ) aged $>12$ years old who come for treatment to all community health centers that have Microscopic Reference Center (MRC) facility and use Directly Observed Treatment Shortcourse (DOTS) strategy in Medan. The sample is selected by consecutive sampling.

There is a significant difference $(\mathrm{p}<0.05)$ of the risk of pulmonary TB transmission according to the role of the DSS between the treatment groups using plastic bags containers and plastic bottles with control group. There is a significant difference $(\mathrm{p}<0.05)$ the risk of pulmonary tuberculosis transmission based on drug compliance between the treatment groups using plastic bagcontainers and plastic bottles with control group. The use of containers containing

the killer disinfectant of TB bacilli in sputum accompanied by promotional messages on the walls of the container is effective in reducing the risk of TB transmission from patients with Acid Fast Bacilli positive $(\mathrm{AFB}+)$ pulmonary $\mathrm{TB}$.
\end{abstract}

Keywords: Pulmonary TB, plastic containers, DSS, Clorofenol.

\section{Introduction}

TB is a contagious infectious disease caused by the Mycobacterium Tuberculosis, which can attack various

\section{Corresponding Author:}

\section{Sorimuda Sarumpaet}

Lecturer of Department of Epidemiology, Faculty of Public Health, Universitas Sumatera Utara, 20155, Medan, Indonesia

e-mail: sorimuda_sarumpaet@yahoo.com organs, especially the lungs. If not treated or the treatment is incomplete, can cause dangerous complications, even death ${ }^{1-3}$.

Globally, in 2016 there were 10.4 million of TB cases (CI: 8.8 million - 12 million) it equivalent to 120 cases per 100,000 population. Five countries with the highest number of cases are India, Indonesia, China, Philippines, and Pakistan. Most of the TB incidence in 2016 occurred in the Southeast Asia Region (45\%), where Indonesia is one of them ${ }^{4,5}$. 
According to the World Health Organization (WHO), in 2016 Korea was one of the countries with the highest number of TB incidence among other highincome countries, it is estimated at 77 cases per 100,000 population ${ }^{6}$.

Based on the Integrated TB Information System report in 2016, TB incidence rate in Indonesia estimated to be at 129 per 100,000 population, it still lower than the reality and almost 2 times higher than Korea ${ }^{1}$ According to the Indonesia Health Ministry the number of tuberculosis was 330,910 cases, this number increased compared to 2014 , which amounted to 324,539 cases.

The WHOdefines the high burden countries (HBC) for tuberculosis according to 3 indicators:TB, Human Immuno Virus TB (HIV-TB), and Multi Drugs Resistance TB (MDR-TB). A country can be included in one of these lists, or both, and can even be included in all three. Indonesia along with 13 other countries are included in the HBC list for all 3 indicators. It means that Indonesia has major problems in dealing with TB.

Cough is the main mechanism of Mycobacterium TB transmission by Esmail et al, ${ }^{8}$ and is transmitted through aerosol which spread in the air with very small range of $1-5 \mu \mathrm{m}^{9}$. Various respiratory activities which produce aerosols, in addition to coughing, can also be through sneezing, singing, and talking. The cough frequency is associated with infectivity but not necessarily the cause of TB transmission ${ }^{10}$. Pulmonary TB patients who often cough do not necessarily transmit, in this case the ethics when coughing plays an important role in preventing transmission of pulmonary tuberculosis ${ }^{11}$.

This researchis carried out for the patients with pulmonary $\mathrm{TB} \mathrm{AFB}+$ to dispose sputum and material contacted with sputuminto container containing klorofenolcompound with 5\%concentration. The container serves as a disposal place of tissues, disposable masks, and sputum from patients with pulmonaryTBAFB + as a killer of Mycobacterium TB after being deposited within 24 hours.

Klorofenolis a derivative disinfectant of phenol (carbolic acid), Giacomelli, et al. ${ }^{12}$ report that $5 \%$ of phenol was effective in decontamination of Mycobacterium TB smear slides for 10 minutes. A study by Sarumpaet and Syarifah ${ }^{13}$ states that the DSS role in assisting drug swallowing and sputum examination is very lacking. Drug compliance must be done to cure pulmonary TB and the role or the activeness of DSS is expected to support the patient recovery .

Based on this, research needs to be carried out on the role of DSS in reducing the risk of TB transmission and the adherence of patients with pulmonary TB-AFB+ in swallowing drugs supplemented by the intervention of containers and waterproof plastic bottles containing $5 \%$ of klorofenolsolution.

The aim and benefit of the study is to analyze the differences in the transmissionrisk and drug compliance for patients with pulmonary $\mathrm{TB}-\mathrm{AFB}+$ based on the DSS role in the group with plastic bags and waterproof plastic bottles compared to the control group.

\section{Materials and Method}

The researchtype is a quantitative study with quasiexperimental design divided into 3 groups, namely groups that receives bag waterproofplastic container, bottle waterproof plastic container that both contains klorofenol desinfectant with a 5\%concentration accompanied by promotional messages and control group. The container contains a klorofenol5\% which functions as a disposal place of tissues, disposable masks, and sputum as a killer of Mycobacterium TB after being deposited for 24 hours.

Promotional messages are attached to the walls of the containersin order for the patients not to forget to take medicine, the effects if they forget to take medicine, always use mask and tissues to cover mouth when coughing, and how to prepare 5\% klorofenolcompound into the containers.

The population and sample are all patients with pulmonary TB-AFB + is aged $>12$ years old who come for treatment with DOTS strategy to all community health centers that have MRCfacilityin Medan. The sample is followed for 2 months and in the last evaluation obtained 125 patientfrom all MRC. The duration of the intervention for 2 months is based on the evaluation of sputum examination conducted at the MRC to assess the conversion of AFB smear positive sputum to smear negative. During the observation in this study, all patients experienced sputum conversion from smear positive to smear negative.

The effectiveness of the use of bag and bottle plastic containers as a model to reduce the transmissionrisk of pulmonary $\mathrm{TB}-\mathrm{AFB}+$ compared to control is performed through a 2 proportions z-test. 


\section{Results}

The samples are taken purposively, that all pulmonary $\mathrm{TB}-\mathrm{AFB}+$ patients who come for treatment at 10 health centers with the highest number of pulmonary TB patients visit, obtained from the health center report data in Medan. The study is amounting to 125 patients, with 34 people getting bottles waterproof plastic (Helvetia and Sentosa Baru Health Center), 40 people gettingbags waterproof plastic (Amplas, Desa Binjai, Medan Johor, and Teladan Health Center), and 51 people for control (Kampung Baru, Medan Deli, Belawan, and Mandala Health Center).

In accordance with the results of the study, the proportion distribution of the patients obtained based on the intervention is in the following Table 1.

Table 1. The Proportion Distribution Of Pulmonary Tb-Afb+ Patients Based On Intervention In Medan Health Center

\begin{tabular}{|l|c|c|}
\hline Intervention Type in Health Center & $\mathrm{n}$ & $\%$ \\
\hline Bottle Waterproof Plastic Group & \multicolumn{2}{|l|}{} \\
\hline Helvetia & 21 & 16.8 \\
\hline Sentosa Baru & 13 & 10.4 \\
\hline Bag Waterproof Plastic Group & 21 & 16.8 \\
\hline Amplas & 5 & 4 \\
\hline Desa Binjai & 10 & 8 \\
\hline Medan Johor & 4 & 3.2 \\
\hline Teladan & \multicolumn{2}{|l|}{} \\
\hline Control Group & 16 & 12.8 \\
\hline Kampung Baru & 8 & 6.4 \\
\hline Medan Deli & 21 & 16.8 \\
\hline Belawan & 6 & 4.8 \\
\hline Mandala & 125 & 100.0 \\
\hline Total
\end{tabular}

Table 2. The Differences In Transmission Risk of Pulmonary Tb-Afb+ Based on the Dss Role in the Intervention And Control Group

\begin{tabular}{|l|c|c|c|c|c|}
\hline Intervention & Nn & Mean & SD & Pp & $\begin{array}{c}\text { Median } \\
(\mathbf{m i n}-\mathbf{m a x})\end{array}$ \\
\hline Bottle & 34 & 1.03 & 1.359 & & $0(0-5)$ \\
\hline Bag & 40 & 0.73 & 1.037 & \multirow{2}{*}{0.000} & $0(0-4)$ \\
\hline Control group & 51 & 4.73 & 3.219 & & $5(0-10)$ \\
\cline { 1 - 2 }
\end{tabular}

With the Kruskal-Wallis test, obtained the value of $\mathrm{p}<0.05$, thereforeconcluded that there is a difference in the risk of pulmonary TB-AFB + transmission based on the role of DSS between the three intervention groups.

In order todiscover the differences in the transmission risk of pulmonary TB between each intervention and control group, a Post-Hoc analysis using the MannWhitney test can be seen in Table 3 below.

Table 3. The Difference In Transmission Risk Of Pulmonary Tb Based On The Role Of Dss Between Each Intervention and Control Group

\begin{tabular}{|l|c|}
\hline Intervention & P \\
\hline Bottle and Bag & 0.404 \\
\hline Bottle and Control & 0.000 \\
\hline Bag and Control & 0.000 \\
\hline
\end{tabular}

Based on table 3, concluded that there is no difference in the transmission risk of pulmonaryTB$\mathrm{AFB}+$ based on the role of DSS between intervention groups that use bottles and bags. However, there is a significant difference $(p<0.05)$ of the transmission risk of pulmonary TB-AFB + based on the role of DSS between the intervention groups using bottles and control group as well as between the intervention groups using bags and control group.

The difference in the transmission risk of pulmonary TB-AFB + based on drugs compliance can be seen from the following table 4 .

Table 4. The Differences InThe Transmission Risk Of Pulmonary Tb-Afb+ Based On Drugs Compliance

\begin{tabular}{|l|c|c|c|c|c|}
\hline Intervention & $\mathbf{n}$ & Mean & SD & $\mathbf{p}$ & $\begin{array}{c}\text { Median } \\
(\mathbf{m i n}-\mathbf{m a x})\end{array}$ \\
\hline Bottle & 34 & 0.18 & 0.378 & & $0(0-1)$ \\
\hline Bag & 40 & 0.23 & 0.480 & \multirow{2}{*}{0.000} & $0(0-2)$ \\
\hline Control group & 51 & 0.96 & 0.799 & & $1(0-3)$ \\
\hline
\end{tabular}

With the Kruskal-Wallis test, obtained the value of $p<0.05$, meaning that there is a difference in the transmission risk of pulmonary $\mathrm{TB}-\mathrm{AFB}+$ based on drugs compliance between the three intervention groups.

To find out the differences between each intervention group, Post Hoc analysis is performed with the MannWhitney test which can be seen in table 5 below. 
Table 5. The Difference In The Transmission

Risk Of Pulmonary Tb-Afb+ Based On Drugs Compliance

\begin{tabular}{|l|c|}
\hline Intervention & P \\
\hline Bottle and Bag & 0.762 \\
\hline Bottle and Control group & 0.000 \\
\hline Bag and Control group & 0.000 \\
\hline
\end{tabular}
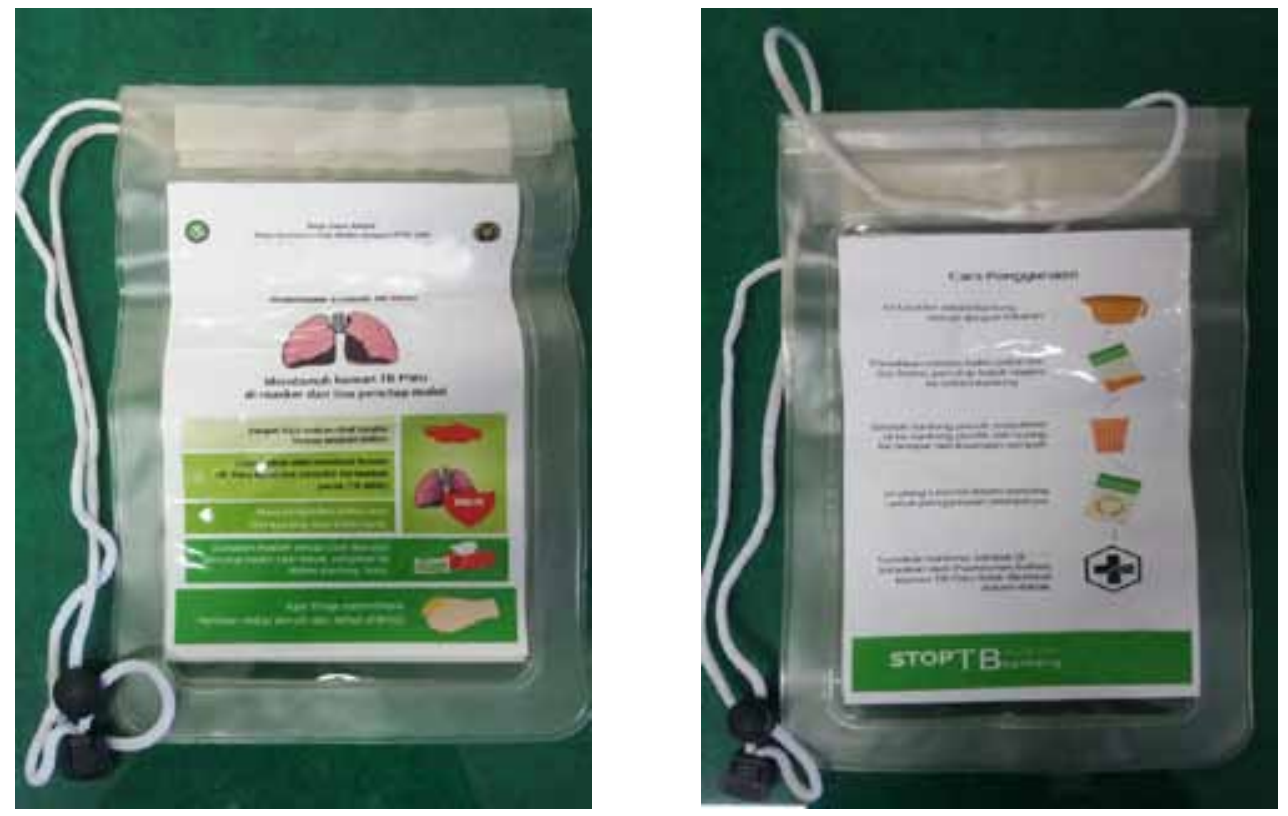

Figure 1. Container Image
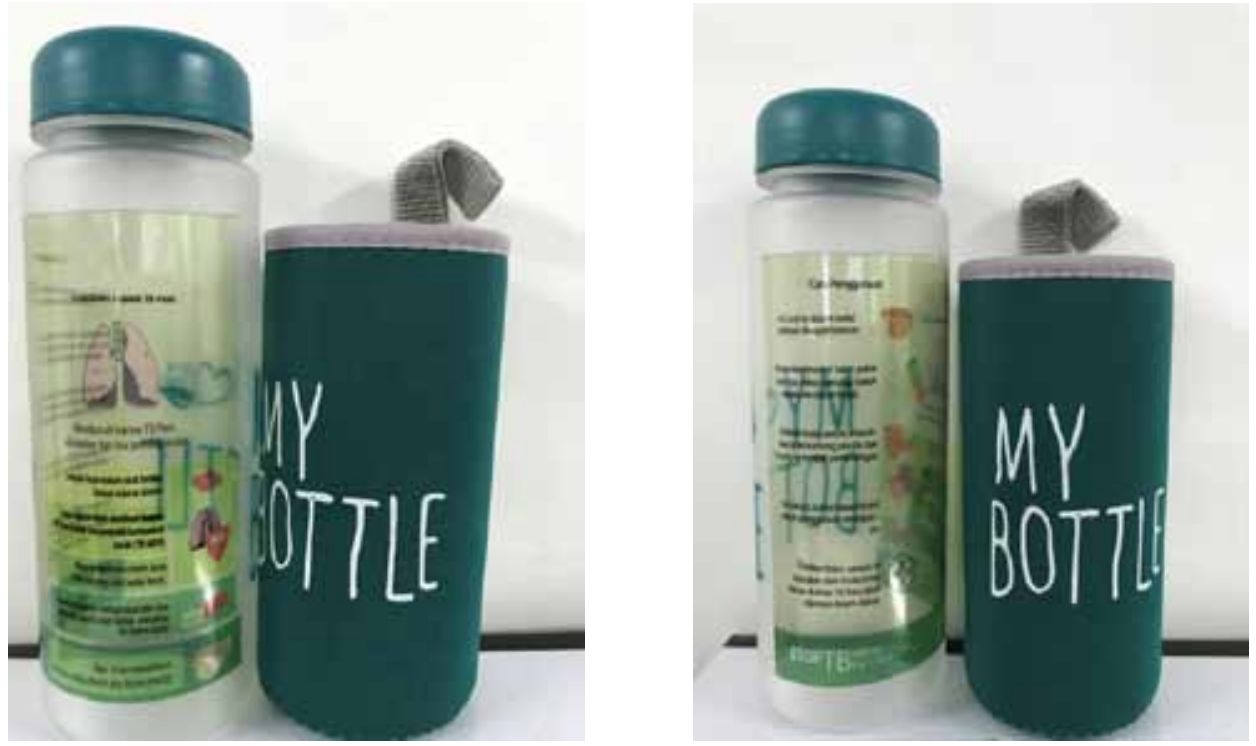

Figure 2. Bottle Image 


\section{Discussion}

The result exhibits a significant difference in the risk of transmission of pulmonary $\mathrm{TB}-\mathrm{AFB}+$ based on the role of DSS between intervention groups using bag and bottle containers with control group group.

The DSS role as supervisors to remind patients to take the medication, accompanying in fetching the drugs, knowing the side effects of TB drugs, and how to dispose sputum is conveyed by the researchers when taking the samples of pulmonary $\mathrm{TB}-\mathrm{AFB}+$ patients who came to the health center at the time of the study.

With the container and the message printed on the sides of the container given to the TB patients, the promotional message can be read at any time therefore the DSS message is more easily remembered by the patients in terms of disposing sputum, as well as the regularity and compliance with the drug. Similarly, the message also will be able to increase the patients knowledge in dealing with their illnesses as the lack of the patients knowledge will make it more difficult to achieve recovery ${ }^{14}$. The patients' knowledge about symptoms, signs, causes, transmission, and treatment are also the key in preventing pulmonary TB transmission ${ }^{15}$. Under these conditions,assumed that the transmission risk is smaller in patients who are given the containers than those without the containers.

The DSS role is a strategy to ensure the patients recovery with pulmonary TB (National Strategy for TB 2010-2014) ${ }^{21}$. A study by Firdaus $\mathrm{KMZ}^{16}$ in Baki Sukoharjo Health Center shows that there is an influence on the role of DSS with the success of the treatment of patients with pulmonary TB-AFB $+(p=0.002)$.

Researchers Suprajitno, et al conclude that when there are mild side effects in patients with pulmonary TB, DSS can provide information to patients that it is natural and take appropriate action to overcome the side effects. Thus the patient is expected not to stop the drug and the transmission risk becomes smaller ${ }^{17}$.

This research is also revealed that thereis a significant difference in the transmission risk of pulmonary TB based on the drugs compliance between the intervention using bottle containers and plastic bag containers with control group. The study results of Latifatul and Umdatus also displays that there is a significant influence between family support on drugs compliance $(\mathrm{OR}=21.99, \mathrm{p}=$ 0.028). According to research conducted by Wiwit and
Amila in 2018, the role of DSS for pulmonary TBpatients is as a motivator, reminding sputum re-examination, supervising treatment as well as the role of educator. Furthermore, according to Rohmana, et al in 2014 that one of the factors that determine the regularity of drugs compliance of pulmonary TB patients is DSS.

Hartini $\mathrm{T}^{18}$ stated that the highest DSS proportion of the patients with pulmonary TB-AFB+in Deli Serdang Regional Hospital in 2011-2012is family (81.5\%). Drugs compliance is the key to the patient recovery with pulmonary TB. Since 1995 the Indonesian government has launched a program to eradicate pulmonary TB by using the DOTS strategy, which is a direct supervision of short-term treatment ${ }^{19}$.

In accordance with the results of research conducted by Pameswari et $\mathrm{al}^{19}$ at Mayjen H.A Thalib Hospital in Kerinci Regency, it is discovered that the number of respondents who adhered to the treatment of pulmonary TBis higher than the number of patients who are semiadherent or non-adherent patients. Out of the 27,the adherent respondents is 15 respondents $(55.56 \%)$, semiadherent is 9 respondents (33.33\%), and non-adherent is 3 respondents $(11.11 \%)$.

A study in India explains most of the disobedience and low motivation to seek treatment are due to lack of knowledge and awareness about the disease ${ }^{20}$. The same thing is concluded from a research in Nepal, the adherence of the patients with pulmonary tuberculosis is related to the compliance, perceptions about $\mathrm{TB}$, and its treatment ${ }^{21}$.

\section{Conclusion}

The use of bags and bottle plastic containers containing the killer disinfectant for TB bacilli in sputum accompanied by promotional messages on the sides of the container is effective in reducing the risk of $\mathrm{TB}$ transmission from patients with pulmonary $\mathrm{TB} \mathrm{AFB}+$.

\section{Conflict of Interest: None}

Source Of Funding: This study is supported by Directorate General of Higher Education, Ministry of Education and Culture, Indonesia (Scheme: No.255/ UN5.2.3.1/PPM/KP-DRPM/2018).

Ethical Clearance: From the university committee. 


\section{References}

1. Kementerian Kesehatan RI, Infodatin Tuberkulosis. http://www.depkes.go.id/download. php?file=download/pusdatin/infodatin/InfoDatin2016-TB.pdf.2016.

2. Kementerian Kesehatan RI, Infodatin Tuberkulosis. http://www.depkes.go.id/download. php?file=download/pusdatin/infodatin/InfoDatin2016-TB.pdf.2016.

3. Kementerian Kesehatan RI. Profil Kesehatan Indonesia 2015. Sekertariat Jenderal Profil Kesehatan Indonesia 2015. Jakarta: Kemeterian Kesehatan RI. http://www.depkes.go.id/resources/ download/pusdatin/profilkesehatan-indonesia/ profil-kesehatan-Indonesia-2015.pdf

4. Kementerian Kesehatan RI, InfodatinTuberkulosis 2018. http://www.pusdatin.kemkes.go.id/pdf. php?id=18101500001.

5. Kementerian Kesehatan RI, InfodatinTuberkulosis 2018. http://www.pusdatin.kemkes.go.id/pdf. php?id=18101500001.

6. World Health Organization. Global Tuberculosis Report.WHO/HTM/TB/2017.23. Geneva, Switzerland: WHO, 2017.

https://www.who.int/tb/publications/global_report/ gtbr2017_main_text.pdf

7. World Health Organization (WHO). Global tuberculosis report 2016. WHO/HTM/TB/2016.13. Geneva, Switzerland: WHO,2016

ht t p s : / / a p p s.who.int/iris/bits tre am/10665/250441/1/9789241565394-eng.pdf

8. Esmail H., Dodd PJ., Houben RMGJ., Tuberculosis transmission during the subclinical period: could unrelated cough play a part?. 6: 244-246. DOI: 10.1016/S2213-2600(18)30105-X. 2018. http:// www.rdm.ox.ac.uk/publication/832428.

9. Loudon RG \& Spohn SK. Cough frequency and infectivity in patients with pulmonary tuberculosis. Am Rev Respir Dis 1969;99(1):109-11. Matched 0003-0805. https://www.ncbi.nlm.nih.gov/ pubmed/5762102

10. Patterson B, Morrow C, Singh V, et al. Detection of Mycobacterium tuberculosisbacilli in bio-aerosols from untreated TB patients. [version 2; referees: 3 approved]. Gates Open Res 2018;1:11. https://www. ncbi.nlm.nih.gov/pmc/articles/PMC5757796/

11. Patterson B., Is Cough Really Necessary for TB
Transmission?. Jurnal Elsivier. DOI: 10.1016/j. tube. 2019.05.003. 2019.

http://www.researchgate.net/publication/333422428.

12. Giacomeli, et al. Improved Laboratory Safety by Decontamination of Unstained Sputum Smears for Acid-Fast Microscopy. J Clin Microbiol. 2005 Aug; 43(8):4245-4248.doi: $\quad$ 10.1128/JCM.43.8.42454248.2005. https://www.ncbi.nlm.nih.gov/pmc/ articles/PMC1233998/

13. Sarumpaet Sorimuda \& Syarifah. Correlation between Pulmonary Tuberculosis (TB) Patient's Characteristics and Role of Supervisor of Drugs Swallowing (DSS) with the Risk of Transmission in Medan City 2017. Indian Journal of Public Health Research and Development 10(1):1209. DOI: 10.5958/0976-5506.2019.00220.1. http:// www.researchgate.net/publication.2019.

14. Udlis, A. K. Self-management in chronic illness: Concept and dimensional analysis. Journal of Nursing and Healthcare of Chronic Illness, 2011;3(2), 130-139. https://onlinelibrary.wiley. com/doi/abs/10.1111/j.1752-9824.2011.01085.x

15. DepKes, R. Profilkesehatanindonesia. Jakarta, Indonesia: DepartemenkesehatanRepublik Indonesia. 2010.

http://www.depkes.go.id/resources/download/pusdatin/ profil-kesehatan-indonesia/profil-kesehatanindonesia-2009.pdf

16. Firdaus, K.M.Z., Pengaruh Peranan Pengawas Menelan Obat (DSS) Terhadap Keberhasilan Pengobatan TB Paru di Wilayah Kerja Puskesmas Baki Sukoharjo. http://eprints.ums.ac.id/21949/20/ NASKAH_PUBLIKASI.pdf.2012.

17. Suprajitno, Iman S, Oky AA., Perception of Supervisor Taking Medicine About The Side Effect of Tuberculosis Medecation for Patients. 2018.; 5:1. DOI:10.26699/jnk.v5i1.ART.p058-061. http:www. researchgate.net/publication.

18. Hartini, T., Karakteristik Penderita Tuberkulosis Paru BTA Positif dan Hasil Pengobatannya di Poli Paru RSUD Deli Serdang Tahun 2011-2012. https://jurnal.usu.ac.id/index.php/gkre/article/ view/9827/4315.

19. Pameswari, P., Halim, A., Yustika, L., Tingkat Kepatuhan Penggunaan Obat pada Pasien Tuberkulosis di Rumah Sakit Mayjen H.A. Thalib Kabupaten Kerinci. Jurnal Sains Farmasi dan Klinis p- ISSN : 2407-7062, e- ISSN 2442-5435. 
2015. http://jsfk.ffarmasi.unand. ac.id/index.php/ jsfk/article/view/60/64.

20. Sakalle, S., Waskel, B., Dixit, S., Pandey, D., Sirohi, S., \& Saroshe, S. A study on patient compliance of tuberculosis enrolled under revised national tuberculosis control programme. National Journal Community Medicine,2014; 5, 96-99. http://njcmindia.org/uploads/5-1_96-99.pdf
21. Keiwkarnka, B., Sermsri, S., Shiyalap, K., \& Nepal, A. K. Compliance with DOTS among tuberculosis patients under community based DOTS strategy in Palpa District, Nepal. International Journal of Infection and Microbiology, 2012; 1(1), 14-19. doi:10.3126/ijim.v1i1.6717.https://www.nepjol. info/index.php/IJIM/article/view/6717. 